\title{
PEMBATASAN KEBEBASAN BERPENDAPAT DI ERA DIGITAL
}

\author{
Andi Riska ${ }^{1}$, Harjun Rouf ${ }^{2}$, M.Yusril ${ }^{3}$, Yolanda Tresna DA \\ ${ }^{1}$ Sekolah Tinggi Ilmu Hukum Amsir, Pare - pare, andiriskarevisanuralam@gmail.com \\ ${ }^{2}$ Sekolah Tinggi Ilmu Hukum Amsir, Pare - pare, harjunrouf46@gmail.com \\ ${ }^{3}$ Sekolah Tinggi Ilmu Hukum Amsir, Pare - pare, myusril342@gmail.com \\ ${ }^{4}$ Sekolah Tinggi Ilmu Hukum Amsir, Pare - pareyolandatresna71@gmail.com
}

\begin{abstract}
:
Democracy as an Indonesian goverment system has implications fpr equal rights, obligations and equal treatment for all its citizen.Freedom of opinion is basically a right owned by every individual guaranteed by the constitution this is contained in Article 28E paragraph (3). The advancement of technology and information is one of the platforms in the delivery of opinions by the people in Indonesia. Communication of technology with various kinds of social media has given freedom to each individual to express their opinions through various types of social media communication. The development of information technology media is charaterized by various problems. The limitation of human rightsin various aspects is a form of control over the avoidance of brutal and transgressing freedom.
\end{abstract}

Keywords : Freedom Of Opinion, Democracy,Communication Information Technology (ICT)

\section{Pendahuluan}

Demokrasi merupakan pandangan hidup yang mengutamakan persamaan hak dan kewajiban serta perlakuan yang sama bagi semua warga negara. Awal istilah "demokrasi" dapat dilihat melalui peradaban Yunani kuno yang bercorak polis. Sistem ini didasarkan pada mayoritas dalam pemungutan suara. Demokrasi secara luas mampu diterima dibandingkan dengan sistem lainnya. Sebagian besar negara di dunia telah melaksanakan praktek dari sistem demokrasi. Sistem ini lebih unggul dibanding dengan sistem lainnya disebabkan karena demokrasi memberikan perlindungan terhadap hak asasi manusia (HAM).

Menurut Aristoteles, suatu negara bisa dikatakan baik jika diarahkan pada kepentingan umum, untuk semua individu rakyatnya, sedangkan jika diarahkan ke penguasa ia dikategorikan buruk. Landasan negara demokratis adalah kebebasan.

Media sosial sebagai ruang publik memberikan dampak positif dalam negara demokrasi. Pasalnya aspirasi publik dapat diserap melalui media sosial. Namun dalam praktiknya terdapat beberapa pelanggaran oleh penggunanya.Kebebasan dalam berekspresi dan berpendapat jelas merupakan bentuk HAM yang tidak boleh dilanggar. Akan tetapi dalam konteks negara demokrasi, keamanan dan kenyamanan bernegara adalah hal yang perlu 
dijamin oleh pemerintah melalui kewenangannya dalam mengatur suatu negara karena penegakan hukum merupakan variable demokrasi. Dalam pembahasan ini akan diuraikan batasan kebebasan dalam konteks bermedia sosial.

Kebebasan berpendapat merupakan hak setiap individu sejak dilahirkan yang telah dijamin oleh konstitusi. Maka, Negara Indonesia sebagai negara hukum dan demokratis berwenang untuk mengatur dan melindungi pelaksanaannya. Kemerdekaan berpikir dan mengeluarkan pendapat tersebut diatur dalam perubahan keempat Undang-Undang Dasar Republik Indonesia tahun 1945 Pasal 28 E ayat (3) Setiap orang berhak atas kebebasan berserikat, berkumpul, dan mengeluarkan pendapat. Kebebasan berekspresi termasuk kebebasan berpendapat merupakan salah satu hak paling mendasar dalam kehidupan bernegara. Undang-undang No. 9 Tahun 1998 tentang Kemerdekaan Menyampaikan Pendapat di muka umum pasal 1 ayat (1) kemerdekaan menyampaikan pendapat adalah hak setiap warga negara untuk menyampaikan pikiran dengan lisan, tulisan, dan sebagainya secara bebas dan bertanggung jawab sesuai dengan ketentuan peraturan perundangundangan yang berlaku.

\section{Metode Penelitian}

Penelitian ini menggunakan metode penelitian normatif, yakni suatu prosedur penelitian ilmiah untuk menemupakan kebenaran berdasarkan logika keilmuan dari sisi normatifnya. Sisi normatif disini tidak sebatas pada peraturan perundangundangan saja.Penelitian hukum normatif mengacu konsep hukum sebagai kaidah dengan metodenya yang doktrinal-nomologik yang bertitik tolak pada kaidah ajaran yang mengkaidai perilaku.(Syahruddin Nawi, 2017: 9)

\section{Analisis Dan Pembahasan}

\section{Konsep Hak Kebebasan Berekspresi dan Berpendapat}

Hak merupakan bagian yang tidak terpisahkan dari manusia. Hak mengandung unsur perlindungan, kepentingan, dan kehendak. Hak selalu berkolerasi dengan kewajiban sebagai bentuk keseimbangan dalam hidup bermasyarakat. Keseimbangan antara hak, kewajiban, dan tanggungjawab merupakan bentuk keseimbangan dalam hidup bermasyarakat. Kesadaran akan adanya suatu tanggungjawab atas setiap perbuatan akan memberikan dampak pada anggota masyarakat harus terus ditanamkan. Kekuatan akan rasa tanggungjawab memberikan implikasi atas kehati-hatian dalam melakukan suatu perbuatan. 
Kebebasan berekspresi dan berpendapat dimaknai sebagai hak yang melekat pada setiap manusia, untuk memiliki. Kebebasan berekspresi digunakan untuk menyampaikan pandangan dan pendapat, baik antar individu atau kelompok(Wiratraman ,2016:51). Konsep HAM dalam hal kebebeasan berekspresi dan berpendapat berkaitan dengan konsepsi negara hukum. Indonesia mengatur kebebasan berpendapat dan berekspresi dalam Pasal 28E ayat (3) "setiap orang berhak atas kebebasan berserikat, berkumpul dan mengeluarkan pendapat." Pasal 28F "Setiap orang berhak untuk berkomunikasi dan memperoleh informasi untuk mengembangkan pribadi dan lingkungan sosialnya, serta berhak untuk mencari, memperoleh memiliki mengelolah, menyampaikan informasi dengan menggunakan segala jenis saluran tersedia."

Saat ini, warga negara secara legal dapat menyampaikan kritiknya terhadap setiap kebijakan publik yang dirumuskan oleh pemerintah dan lembaga negara, sehingga apabila kebijakan tersebut tidak memenuhi tujuan kebijakan publik tersebut maka kebijakan tersebut dapat dikendalikan oleh masyarakat sendiri.Belakangan ini, berbagai organisasi yang didedikasikan untuk kebebasan berekspresi telah bermunculan. Tujuan dari sebagian besar organisasi yang ada adalah menjadi sarana bagi warga negara untuk menyampaikan semua pendapat dan saran mereka, pendapat dan saran ini akan dikomunikasikan oleh organisasi-organisasi ini atau membantu parapengambil keputusan untuk mendengarkan.

Menjadikan kehidupan negara dan negara saling mengikat. Namun, proses kebebasan berbicara di Indonesia tidak terlepas dari penyalahgunaan kebebasan berbicara, karena penyalahgunaan kebebasan berbicara dapat mengakibatkan perpecahan jangka panjang. Karena kurangnya kontrol, kebebasan berbicara disalahgunakan. Tanpa kontrol yang jelas, warga akan terlalu percaya bahwa semua kebijakan yang merugikan diri sendiri dan organisasinya akan ditentang dengan alasan kebebasan berpendapat dan dianggap sebagai kebijakan yang tidak relevan.

\section{Minoritas Menguasai Mayoritas}

Indonesia adalah negara yang diatur oleh hukum, dan tentunya ada peraturan perundang-undangan yang melindungi hak asasi manusia. Keberadaan hak asasi manusia sebenarnya tidak diberikan oleh negara, tetapi hak asasi manusia hipotetis adalah hak individu yang bersifat supranatural, dan setiap orang memilikinya sejak lahir. Setiapmasyarakat di Indonesia memiliki hak untuk berbicara dan menyampaikan pendapat, tanpa memandang ras, ras, atau agamanya. Teknologi informasi saat ini menjadi pedang bermata dua, karena tidak hanya membantu meningkatkan kesejahteraan, kemajuanmanusia dan peradaban, tetapi juga sarana efektif untuk perilaku ilegal. 
Pengiriman dan penyebaran informasi melalui media cetak dan elektronik biasanyamengikuti aturan umum masyarakat.Dalam Pasal 2 ayat (1), Ketetapan Nomor 9 Tahun 1998 disebutkan: "Setiap warga negara, baik individu maupun kelompok bebas, mengungkapkan pandangannya sendiri- sendiri, yang mewujudkan kehidupan demokrasi di negara tersebut sebagai masyarakat dan negara. Hak dan tanggung jawab.tujuan kebebasan berpendapat di depan umum adalah untuk mewujudkan kebebasan yang bertanggung jawab sesuai dengan "Pancasla" dan UUD 1945, sebagai salah satu sarana untuk mewujudkan hak asasi manusia, dan mewujudkan hukum yang konsisten dan berkelanjutan dalam rangka menjamin kebebasan berekspresi.

\section{Demokrasi dan Kebebasan Berekspresi dan Berpendapat Era Digital}

Demokrasi memberikan peluang kepada setiap orang untuk menikmati kebebasan yang dimilikinya secara proporsional karena kebebasan seseorang dibatasi oleh kebebasan orang lain (Selian \& Melian 2018 : 191). Kebebasan Berekspresi merupakan elemen penting dalam jalannya demokrasi dan partisipasi publik. Hal ini diperlukan agar terciptanya partisipasi publik dalam pengabilan kebijakan publik atau dalam hal pemungutan suara. Apabila masyarakat kebebasannya dilanggar maka dapat dikatakan pemerintahan telah berlangsung secara otoriter.

Sebagai upaya pencegahan kebebasan berekspresi dan berpendapat yang kebablasan, yakni kebebasan berekspresi dibatasi oleh undang-undang, jiwa (morality) masyarakat, ketertiban sosial dan politik (publik order) masyarakat demokratis. Maka dapat ditarik suatu kesimpulan bahwa dimana kebebasan berekspresi itu hidup akan turut memberi andil mengenai cara kebebasan berekspresi itu diterapkan. Peraturan sebagai terjemahan dari konstitusi diperlukan dalam hal mengenai batasan dalam negara penganut hukum positivis. TobyMendel menjelaskan bahwa terdapat beberapa alasan kebebasan berekspresi menjadi hal yang penting: 1). Karena ini merupakan dasar demokrasi; 2). Kebebasan berekspresi berperan dalam pemberantasan korupsi; 3). Kebebasan berekspresi mempromosikan akuntabilitas; 4). Kebebasan berekspresi dalam masyarakat dipercaya merupakan cara terbaik menemukan kebenaran. Adapun kebebasan berekspresi tidaklah mutlak, dalam UDHR menyebutkan bahwa kebebasan berekspresi ini tidak berarti bebas sebebasbebasnya. Kebebasan berekspresi memiliki Kebebasan berekspresi pun mempunyai batasan. Pasal 19 Declarationof Human Rights menyatakan: "(1)Everyone has duties to the community in which alone the free and full Development of his personality is possible. (2) in the exercise of his rights and freedom, everyone shall be subject to such limitations are determined by law solely flr the purpose of securing due recognition and reapect fpr the rights and freedoms of 
others and of meeting the just requirements of morality, publik order, and the welfare in democratic society".

\section{Pengaruh Oligarki dalam Demokrasi}

Hal yang menyatakan kebebasan berpendapat tercantum di dalam pancasila yang berbunyi ; "Kerakyatan Yang Dipimpin Oleh Hikmat Kebijaksanaan Dalam Permusyawaratan Perwakilan", yang memiliki arti sebagai berikut :

a. Kekuasaan Rakyat Adalah Segalanya

Makna dari empat sila pertama Pancasila adalah bahwa sebenarnya rakyat Indonesia memiliki kedaulatan tertinggi di negaranya yang menjadi pedoman dalam melaksanakan setiap keputusan pemerintah. Hal ini karena hak dan kewajiban warga negara lebih berperan dalam partisipasi atau partisipasi dalam pembangun.

b. Menghargai Keputusan

Makna dari empat prinsip Pancasila dalam kehidupan berbangsa dan bernegara adalah saling menghormati dan menghargai setiap keputusan yang disepakati bersama. Ini penting karena bisa menghilangkan segala macam konflik di masyarakat.

c. Demokrasi

Makna sila keempat Pancasila adalah menegakkan demokrasi dari segala aspek kehidupan bermasyarakat. Di bidang politik nasional, hubungan ekonomi dan budaya dan manajemen sosial.

d. Mufakat

Makna dari keempat sila Pancasila lainnya adalah membuat berbagai bentuk pengambilan keputusan secara kolektif, keputusan bersama tersebut mengutamakan berbagai prinsip sesuai dengan ideologi adat masyarakat, yaitu musyawarah yang mencari mufakat.

e. Berani Bertanggung Jawab

Arti dari empat prinsip terakhir Pancasila adalah memberikan tanggung jawab untuk melaksanakan keputusan. Mengingat tidak adanya rasa tanggung jawab maka kebijakan tersebut akan melenceng dari seluruh kebutuhan masyarakat, hal ini tentunya merupakan hal yang mutlak dan akan kita bahas secara detail.

\section{Penyebab Hak Kebebasan Yang Kian Menyempit}

Kebebasan berpendapat adalah salah satu hak asasi yang dimiliki oleh setiap warga negara dan ini adalah hak konstitusional yang dijamin oleh negara. Negara Indonesia sebagai negara hukum dan demokrasi berwenang mengatur dan melindungi pelaksanaan Hak Asasi Manusia. Hal ini diaminkan dalam perubahan keempat Undang- Undang Dasar Negara Republik Indonesia 1945 pada Pasal 28E ayat (3) yang mengemukakan bahwa "setiap orang 
berhak atas kebebasan berserikat, berkumpul, dan mengeluarkan pendapat." Kemudian penafsiran dari pasal tersebut diakomodir melalui Undang-undang Nomor 9 Tahun 1998 tentang Kemerdekaan Menyampaikan Pendapat di Muka Umum Pasal 1 ayat (1) "kemerdekaan menyampaikan pikiran dengan lisan, tulisan dan sebagainya secara bebas dan bertanggungjawab sesuai dengan ketentuan perundangan yang berlaku".

Media eletronik dan media sosial menjadi platform mengalirnya berbagai informasi dan tentu ini menjadi wadah bagi warga negara untuk berpendapat dan berekspresi. Dalam konteks negara demokrasi media mampu menjadi wadah penyampaian aspirasi publik. Media sosial memberikan dampak terhadap karakter baru, audience generated media memungkinkan publik untuk mendistribusikan konten yang mereka himpun sendiri.

Praktik produce-sage berarti memproduksi sekaligus mengkonsumsi konten. Hal negatif yang terekam adalah kecenderungan berpendapat di media sosial yang mulai diwarnai dengan konten negatif. Munculnya fenomena culturelag, keberadaan media sosial berbanding terbalik dengan kemampuan literasi, sehingga media sebagai ruang publik cenderung berubah menjadi wadah yang berisi konten negatif. Media sosial merupakan salah satu upaya mobilitas yang efektif dan inovatif untuk menggerakkan masyarakat. Maka dengan demikian pada akhirnya perkembangan teknologi informasi melalui media sosial menimbulkan kedinamisan dalam sajian informasi dengan berbagai elektronik (Smartphone, Notebook, Tablet, dll).

Kebebasan berpendapat memiliki tanggung jawab dan dibatasi oleh hukum yang dibutuhkan demi menghormati hak dan repotasi orang lain, perlindungan keamanan negara, kesehatan dan moral publik. Ketentuan Pasal 19 (3) ICCPR "The exercise of the rights Provided for in paragraph 2 of this article carries with it special duties and responsibilities. It may therefor be subject to certain restrictions, but therse shall only be such as are provided by law and are necessary; (a) For respect of the rights of reputations of others. (b) For the protection national security or of publik order (order publik), or of publik health or morals.

Ketentuan pada Pasal 20 (2) ICCPR menjadi pembatas kebebasan berekspresi dan berpendapat "any advocacy of national, racial, or religoush hatred that constitutes incintement to discrimination or violence shall be prohibited by law". Hal ini sejalan untuk mencegah adanya kebebasan berekspresi dalam bentuk tulisan, gambar, atau audio yang berisis propaganda, ujaran kebencian atas dasar ras, agama atau tindakan diskriminasi lainnya.

\section{Hal yang dapat dilakukan dalam mengemukakan pendapat}

Dalam kita menyampaikan pendapat kita juga harus beretika

1) Menyampaikan pendapat secara sopan 
Jadi jika kita ingin menyampaikan pendapat harus secara sopan dan juga santun, tidak menggunakan kata yang kasar ataupun dengan cara mencaci maki, bila seperti iitu akan timbullah rasa sakit hati pada orang lain.

2) Mengetahui kapasitas pengetahuan diri

Jika kita ingin menyampaikan pendapat, kita juga harus tahu kapasitas pengetahuan dalam diri kita, sehingga bila kita menyampaikan suatu pendapat jelas asal-usulnya,Sehingga tidak menimbulkan konflik saat berpendapat.

3) Memiliki argumen yang kuat

Jadi jika kita berpendapat kita harus memiliki argumen yang kuat, agar tidak salah dalam berbicara.

4) Tidak memotong lawan bicara

Pada saat kita berbicara hendaknya kita menyimak dan mendengarkannya dengan baik, dan membiarkan lawan bicara cara menyampaikan pendapatnya hingga selesai, bila sudah selesai maka kemukakanlah apa pendapat anda.

5) Tidak menyerang lawan bicara

Saat lawan bicara menyampaikan pendapatnya, janganlah kita menyerang lawan bicara, walaupun kita tidak setuju dengan pendapatnya.

Jadi yang menghambat kita untuk berpendapat ialah tidak diterimanya pendapat, kemudian adanya keputusan langsung dari petinggi negara. Jadi apa pun segala keputusan yang ingin dikemukakan bila telah menjadi ketetapan petinggi negara maka keputusan itu tidak akan bisa diubah.

\section{Ruang Kebebasan Berpendapat dan Berekspresikian Menyempit}

Wakil Ketua Eksternal Komnas HAM RI, Amiruddin Al Rahab menyampaikan belakangan telah terjadi adanya fenomena atau perasaan di masyarakat terkait ruang menyatakan pendapat dan kebebasan berekspresi yang kian menyempit. Perasaan menyempitnya ruang kebebasan pendapat dan berekspresi bahkan bukan dirasakan masyarakat, melainkan juga kalangan jurnalis. Dia bahkan menyebut fenomena itu juga semakin menguat dari hari ke hari. Hal itu disampaikan Amiruddin dalam diskusi daring "Demokrasi dan HAM, Refleksi Setahun Kabinet Jokowi-Amin" yang diselenggarakan Komnas HAM.

Amiruddin mengatakan kebebasan berpendapat dan berekspresi sebenarnya sudah dijamin oleh konstitusi. Adanya indikasi penyempitan ruang kebebasan tersebut secara langsungberdampak terhadap hak asasi manusia. Karena itu hal tersebut perlu menjadi perhatian serius.menurut Amiruddin, penyempitan ruang kebebasan tidak hanya disebabkan olehinstitusi negara, melainkan juga kelompok. Komnas HAM sendiri juga telah menyoroti siapasaja pihak yang kemudian bisa mempersempit ruang menyatakan pendapat 
danberekspresi. "Tidak selalu institusi kenegaraan tapi kelompok-kelompok di dalammasyarakat bisa juga mempersempit ruang itu. Artinya apa? Tidak membuka ruangberdiskusi atau berdialog lebih jauh tapi lebih banyak menggunakan tangan aparatur hukum untuk mengatasi perbedaan pendapat dengan kelompok yang lain," kataAmiruddin.

la menuturkan penyempitan ruang kebebasan berpendapat dan berekspresi menjadi lebih berbahaya dan berdampak kepada hak asasi manusia lantaran merambah kepada jurnalis dan media massa. Di mana, saluran informasi baik dari, oleh dan untuk masyarakat melalui media massa jadi terhambat karena penyempitan ruang kebebasan tersebut. "Tanpa kebebasan pers maka hak asasi manusia juga bisa menjadi berkurang. Kenapa? Karena ada dua hal di dalamnya,"ujarAmiruddin."Pertama hak masyarakat untuk menyatakan pendapat atau aspirasinya bisa melalui media massa atau hak masyarkat untuk mendapat informasi. Karena untuk memperoleh hak asasi manusia itu juga bisa terhalangi ketika media tidak lagi merdeka atau media tidak lagi bebas untuk menyatakan pemberitaan atau meliput atau memberitakan sesuatu," tandasnya.

\section{Implementasi Hak Asasi Manusia Terhadap Kebebasan Berpendapat Oleh OrganisasiKemasyarakatan Di Media Sosial.}

Menurut Sam Issacharoff, salah satu bentuk pembatasan yang dapat dibenarkan dandibutuhkan dalam negara demokrasi adalah pembatasan terhadap Negara dapat melarang atau membubarkan suatu organisasi yang bertentangan dengan tujuan dasar dan tatanankonstitusional. Negara demokratis tidak hanya memiliki hak, tetapi juga tugas untukmenjamin dan melindungi prinsip-prinsip demokrasi konstitusional (M. Asfa Firosa, 2019: 156).

Syarat adanya kebebasan untuk menyatakan pendapat dan berserikat, merupakanpersyaratan mutlak yang lain dan harus dimiliki oleh suatu negara demokrasi (termasukIndonesia), maka kebebasan ini harus pula dijamin di dalam undang-undang negara yang bersangkutan. Dalam hal ini termasuk juga Undang-Undang No. 11 Tahun 2008 tentangInformasi dan Transaksi Elektronik yang mengatur pelaksanaan kebebasan menyatakan pendapat melalui media internet.

Undang-undang yang mengatur mengenai kebebasan menyatakan pendapat dan berserikat itu harus dengan tegas menyatakan adanya kebebasan menyatakan pendapat baik secara lisan maupun tertulis. Dalam rangka kebebasan menyatakan pendapat tersebut, maka setiap orang berhak mengumpulkan bahan-bahan yangdibutuhkannya, sehingga harus dijamin pula haknya untuk mencari, memperoleh, memiliki, menyimpan, mengolah dan menyampaikan pendapat tersebut. Dibalik itu perlu pula adanya ketentuan undang-undang yang melarang siapapun, termasuk pemerintah yang ingin mengurangi, membatasi atau meniadakan 
kebebasan dimaksud. Akan tetapi ketentuan yang seharusnya ada tersebut tidak ditemukan dalam Undang-Undang yang mengatur tentang Informasi dan Transaksi Elektronik tersebut.

Kebebasan berpendapat tersebut pada dasarnya merupakan hak dan tanggung jawab negara demokrasi. Demokrasi yang dipahami sebagai pemerintahan dari, oleh, dan untuk rakyat menghendaki adanya partisipasi aktif dari masyarakat untuk turut serta dalampemerintahan. Masyarakat diharapkan mampu melakukan fungsi control terhadap jalannya pemerintahan suatu negara, dengan cara turut menyampaikan pandangan terhadap setiap kebijakan yang ditetapkan pemerintah. Dengan demikian maka secara tidak langsung masyarakat berperan dalam jalannya pemerintahan, melalui jaminan kebebasan berpendapat. Apabila masyarakat tidak diberikan kesempatan untuk menyampaikan pendapatnya kepada pemerintah, maka dapat dikatakan bahwa pemerintahan tersebut bersifat otoriter.

\section{Penutup}

Hak merupakan bagian yang tidak terpisahkan dari manusia. Hak mengandung unsur perlindungan, kepentingan, dan kehendak.Indonesia adalah negara yang diatur oleh hukum, dan tentunya ada peraturan perundang-undangan yang melindungi hak asasi manusia. Setiap masyarakat di Indonesia memiliki hak untuk berbicara dan menyampaikan pendapat, tanpa memandang ras, ras, atau agamanya. Indonesia menjadi salah satu negara demokrasi olenya itu demokrasi memberikan peluang kepada setiap orang untuk menikmati kebebasan yang dimilikinya secara proporsional karena kebebasan seseorang dibatasi oleh kebebasan orang lain. Kebebasan Berekspresi merupakan elemen penting dalam jalannya demokrasi dan partisipasi publik. Apabila masyarakat kebebasannya dilanggar maka dapat dikatakan pemerintahan telah berlangsung secara otoriter.Sebagai upaya pencegahan kebebasan berekspresi dan berpendapat yang kebablasan, yakni kebebasan berekspresi dibatasi oleh undang-undang, jiwa (morality) masyarakat, ketertiban sosial dan politik (publik order) masyarakat demokratis. Hal yang menyatakan kebebasan berpendapat tercantum di dalam pancasila yang berbunyi ; "Kerakyatan Yang Dipimpin Oleh Hikmat Kebijaksanaan Dalam Permusyawaratan Perwakilan". Adapun dalam menyampaikan pendapat kita juga harus beretika: 1) Menyampaikan pendapat secara sopan, 2) Mengetahui kapasitas pengetahuan diri, 3) Memiliki argumen menyangkut, 4) Tidak memotong lawan bicara, 5) Tidak menyerang lawan bicara.

\section{Referensi}

\section{Buku}

Mahfud MD. , 1999, "Pilar Hukum dan Demokrasi". 
M. Asfa Firosa, 2019. "Pembubaran Organisasi Kemasyarakatan dalam Perspektif Hak Kebebasan Berserikat Berdasarkan Konstitusi Negara Republik Indonesia”. Vol. 2/ No. 2. HIm. 156

Sari, Frayunita, Ratih. (2019) "Menyoal Kebablasan Berpendapat: Malfungsi Media Sosial Sebagai Panggung Produsage Konten Negatif" IImu Komunikasi Fispol, Universitas Gajah Mada. Mei.

Selian, D.L., \& Melina, C. (2018). "Kebebasan Berekspresi di Era Demokrasi: Catatan Penegakan Hak Asasi Manusia”, LexScientia Law Review. Volume 2 No. 2, November.

Wiratraman. R. Herlambang Perdana dkk, (2016). "Kebebasan Berekspresi di Indonesia, Lembaga Studi dan Advokasi Mayarakat (Elsam)

\section{PeraturanPerundang-Undangan}

Undang-Undang Dasar Republik Indonesia tahun 1945 Pasal 28 E ayat (3) tentang kebebasan berpendapat.

Undang-undang No. 9 Tahun 1998pasal 1 ayat (1) tentang Kemerdekaan Menyampaikan Pendapat di muka umum.

\section{Sumber Lain}

https://www.kompasiana.com/ksatrya.s.p.f/pelanggaran-keberdekaanberpendapat_54f5e088a33311

https://journal.unnes.ac.id/sju/index.php/lslr/

https://kontras.org/2019/09/16/siaran-pers-hari-demokrasi-internasional-per]-untuk-seluruhrakyat-demokrasi-Indonesia-sedang-di-ujung-tanduk/

https://www.google.com/amp/s/amp.tirto.id/lokaratu-sebut-ruang-ekspresi-publikselian , D.L. dan Melina, C. (2018). "Kebebasan Berekspresi di Era Demokrasi: Catatan Penegakan hak $A$

https://elsam.or.id/internet-shutdown-papua-bentuk-repression-digital-dan-menalahiprincipled-condition- darurat/ sasi Manusia "," LexScientia Legal Review ". November 
Vol. 2 No.2. Rosana (Ellya). (2016) "The SituationofDemocracyand Human Rights", "Tapis Magazine": "Islamic PoliticalAspirations" No. 12, No.1.

https://amp.suara.com/news/2020/10/27/161354/komnas-ham-ruang-keberdekaanberpendapat-and-expression- semakin sempit

http://fusion.rifainstitute.com/index.php/fusion/article/view/18

http://journal.uinjkt.ac.id/index.php/adalah/article/view/16200

https://ejournal.unsrat.ac.id/index.php/administratum/article/view/31266/29969 